\title{
Commentary: The Place of Labor in the History of Information-Technology Revolutions
}

\author{
GREg DOWNEY
}

\section{INTRODUCTION}

As co-editor of this IRSH supplement "Uncovering Labour in Information Revolutions", I have to begin this commentary with a confession. Before I entered the world of abstract knowledge production, commodification, and consumption known as academia, I was myself a worker in a world of much more concrete information processing: I was a computer programmer in the US from the mid-I980s to the mid-I990s, a time we might now consider the nostalgic heyday of desktop-office information technology (IT). ${ }^{\mathrm{I}}$ In the spirit of full disclosure, before I leap into an analysis of how we might more broadly conceptualize information technology together with information labor in different historical contexts, I have decided to work through my own historical narrative a bit. After all, if historical practice teaches us nothing else, it teaches that each of us makes sense of the world through the lens of personal experience, leaving historians (among others) with the daunting task of interpreting, translating, and finding patterns of meaning in those experiences. Thus I offer this candid admission: "I was a teenage information worker!”

And I really was a teen. I began my own IT labors in the early I 980 , not as a producer but as a consumer - buying a home computer and accessories while still in secondary school, and supplementing my lack of in-school exposure to technology with how-to books, so that I could move myself from "computer literacy" to "computer programming". Following the examples I saw in hobbyist magazines, I wrote half a dozen BASIC programs which I then submitted for publication (sadly, all were rejected). Although on one hand I was pursuing valued, high-tech production skills

I. For simplicity's sake, I'm using the shorthand "information technology" to stand in for a set of tools, algorithms, and infrastructures which might more accurately (but not completely) be described as "information production, storage, communication, and processing technology". In other words, the "revolution" is in the way technology enables (and sometimes compels) humans to manipulate, conceptualize, and value information in new ways, whether that information is being transmitted or transported, produced or consumed, stored or processed. 
- fully endorsed by my middle-class parents and my public-school educators - on the other hand I was happily engaged in a nascent consumption community of "geek chic" which remains crucially important to the PC industry today.

I continued this consumption after secondary school through an increasingly prevalent form of technical education (masked as academic education) combined with contingent labor (masked as apprenticeship): I was a computer-science major at a large US public university during the school year, and a "summer intern" at various arms of the US militaryindustrial-academic complex in the summer. One of these summers, due to a labor strike at a defense-contracting aerospace plant where I was working, I was pulled from my 9-to-5, first-shift office job - sitting in front of a computer terminal, cleaning up FORTRAN programs - and placed into a 3-to-I I second-shift factory job, instead - this time standing in front of a computer terminal, manually relaying machine parts that were automatically supplied to me from a robotic rack storage system into the correct little boxes on a passing conveyor belt. I had moved, for a short time, from the white-collar realm of "informatization" to the blue-collar realm of "automation."

Finally, after university, I wove a professional IT career of my own through the US information industry: first as an in-house "analyst" within a large advertising agency, helping multinational consumer-products firms efficiently buy time in increasingly fragmented global mass media; and later as an in-house "programmer" within a small research laboratory, claiming to bridge the gap between psychology, education, and machine intelligence for the benefit of military and corporate training. At the advertising agency, the technical division of labor was coupled with an organizational division of labor: in-house analysts were trained to act (toward other employees) as a sort of outside consulting firm; however, we were valued (by management) precisely because we held secret knowledge about the firm and could supposedly build better IT systems faster than an outside contractor. At the research lab, on the other hand, the technical division of labor ran hand in hand with a social division of labor: programmers (who coded knowledge using programming languages) were almost entirely male, and "indexers" (who coded knowledge using representational languages) were almost entirely female. But male or female, we were nearly all under the age of thirty, and were expected to either quit of our own accord or apply to the lab's spin-off, for-profit consulting company at some point before our job tenure grew too long. Thus did this IT worker, exposed by now to the military and the corporate, the white-collar and the blue-collar, the contingent and the professional aspects of software labor, finally decide to abandon his high-tech career altogether and pursue instead the academic analysis of technology in society. (Well, only after realizing that the ioo résumés I had sent to new, 
stock-option-laden "dot-com" companies in Silicon Valley hadn't generated a single response. As I said, full disclosure.)

Today, in my academic capacity, I am still an information worker. I am paid (quite generously, really) to read and research, to teach and Web-surf, to "publish or perish". In the course of my labors, I consume information, I organize information, I communicate information (the old-fashioned word is "teaching"), and if all goes well, I produce information. As an employee of a large US public university, my salary is paid by a historically shifting combination of taxpayer funds, federal grants, student-tuition dollars, and intellectual property royalties. My position is expected to serve a variety of political-economic goals: building curious, informed, and media-savvy citizens; imparting employer-demanded job skills to new labor force entrants; and enhancing the "competitiveness" of my city, state, region, and nation. Yet I continue to believe, somehow, that I am motivated in this complex situation mainly by the noble pursuit of truth.

So in writing this essay I am vexed with the personal question: do I now, or did I ever, qualify as "information labor" in any sort of useful analytical, structural, or even Marxian sense? Surely my story is not representative of any sort of universal education or career experience through the IT revolution. And perhaps all my story really does is help to explain (though not to excuse) the rather severe bias in what follows toward recent IT history, toward computerized IT labor, toward IT as it has been experienced in the US context, and toward the experience of rather privileged actors within that context. Yet, I am struck by the fact that my personal history maps quite well with the tripartite division of information labor proposed by Aad Blok in the introduction to this volume: (I) labor in producing and reproducing information infrastructures; (2) labor in producing the information which exists in and through these infrastructures; and (3) labor of other sorts which is irrevocably changed through the application of information and its infrastructures. I think we each need to use such personal stories to ask: during moments of profound technological change, how can historians bring individual, contingent, anecdotal histories into wider frameworks? How might we finally begin to define "the labor history of the information technology revolution"?

\section{DEFINING INFORMATION-TECHNOLOGY REVOLUTIONS}

For something said to be so far-reaching, so transformative, and so unprecedented as this information-technology revolution, it might come as a surprise to anyone except historians that there are few if any agreedupon frameworks for conceptualizing, periodizing, explaining, and evaluating that revolution (if in fact "revolution" is the proper term at all). Though the Internet and World Wide Web occupy much of our discussion today - the Pew Internet and American Life Project has 
counted that, in the US, some 37 per cent of all full-time workers (and I 8 per cent of part-time workers) are now equipped with Internet access in their workplace - few would limit the IT revolution to the early i990s combination of CERN's HTML protocols and the NCSA's free browser software that so soon spawned new definitions of social processes like "e-commerce" and "digital divides". ${ }^{2}$

Many assume instead that the latest IT revolution began some time in the mid-I970s, mainly in the US, with the application of microprocessors to a new category of small calculating machines first called "home computers" but later renamed "personal computers" (PCs) as they moved out of the home and into the office. ${ }^{3}$ This marking of the IT revolution is attractive since it seems to correspond with the oft-cited date of 1973 as the herald of a societal shift from "modernity" to "postmodernity". ${ }^{4}$ Quite a few social scientists - from geographers and sociologists to economists and even "futurists" - have pointed to this shift as involving new ways of applying information to global capitalist accumulation: the intensified application of knowledge to production, the increased use of communications to coordinate production at a distance, and the growth of a nonmaterial sector of the productive economy based on services and spectacles rather than on goods and materials. The result is often a new geography of capitalism, whether at the scale of a "megalopolis" or a "new industrial state". F For example, Manuel Castells has argued for conceptualizing an "informational society", writing that even though "information, in its broadest sense, e.g. as communication of knowledge, has been critical in all societies", today we are witnessing "a specific form of social organization in which information generation, processing, and transmission become the fundamental sources of productivity and power, because of new technological conditions emerging in this historical period". 6

2. Pew Internet and American Life Project, http://www.pewinternet.org, last accessed 3 September 2000); Janet Abbate, Inventing the Internet (Cambridge, MA, I999); Tim BernersLee with Mark Fischetti, Weaving the Web: The Original Design and Ultimate Destiny of the World Wide Web by its Inventor (San Francisco, CA, 2000).

3. Ted Nelson, The Home Computer Revolution (South Bend, IN, I977); Paul Freiberger and Michael Swaine, Fire in the Valley: The Making of the Personal Computer, 2nd edn (New York, 1999); Steven Levy, Hackers: The Heroes of the Computer Revolution, updated edn (New York, 200I).

4. David Harvey, The Condition of Postmodernity: An Enquiry into the Origins of Cultural Change (Cambridge, MA, 1989). Others push this date back into the I960s or even I950s, e.g. Fredric Jameson, Postmodernism, or the Cultural Logic of Late Capitalism (London, 1991). 5. Jean Gottmann, Megalopolis: The Urbanized Northeastern Seaboard of the United States (Cambridge, MA, I96I); John Kenneth Galbraith, The New Industrial State (New York, 1967); Daniel Bell, The Coming of Post-Industrial Society: A Venture in Social Forecasting (New York, 1973); Robert B. Reich, The Work of Nations: Preparing Ourselves for 2 Ist Century Capitalism (New York, 1992).

6. Manuel Castells, The Rise of the Network Society, vol. I of The Information Age: Economy, Society and Culture (New York, 1996), p. 21, n. 33. 
Castells went on to tie this new society, a geography at the scale of the "space of flows", directly to the technologies of the PC era.

Yet such claims aren't unique to our own historical period. Others trace the key IT revolution not to personal computers but to what we might call "organizational computers", the transistor-powered "glass-house" corporate mainframes of the I950s and 1960s. ${ }^{7}$ If we abandon computers entirely, we can point instead to early advances in electromechanical punched-card data processing and typewritten record keeping, beginning with the Gilded Age firm. ${ }^{8}$ This date can be pushed back further still, for example to the I840s birth of electromagnetic communication-at-adistance in the first working telegraphs in the US and Britain.9 Even defining the start of the information-technology age in terms of nonelectrical knowledge production techniques is no less valid (and has spawned a cottage industry of research all its own). ${ }^{10}$

Of course, we historians expect claims of "revolution" to be full of ambiguity and debate; our careers turn on our ability to define and defend change as either evolutionary or revolutionary, expected or surprising, universal or time- and place-specific. The technological transition commonly known today as the "second industrial revolution", involving electrical power, industrial chemistry, and fossil-fuel combustion around the turn of the twentieth century, also inspired a crisis of historical reperiodization, from Lewis Mumford's "eotechnic, paleotechnic, and neotechnic" ages to Stephen Kern's assertion that these new technologies ushered in a "crisis of abundance". ${ }^{\text {I }}$

Furthermore, there are plenty of good reasons to believe that other forces, which cannot be reduced to the effects of information technology, are at play in dialectical motion with our current IT revolution. For example, much of the affluent industrial world has for the last two decades been governed under an increasingly powerful ideology of neoliberalism

7. James W. Cortada, "Progenitors of the Information Age: The Development of Chips and Computers", in Alfred D. Chandler, Jr and James W. Cortada (eds), A Nation Transformed by Information: How Information Has Shaped the United States from Colonial Times to the Present (Oxford, 2000), pp. 177-216.

8. JoAnne Yates, "Business Use of Information and Technology during the Industrial Age", in Chandler and Cortada, A Nation Transformed by Information, pp. 107-1 36.

9. Richard R. John, "Recasting the Information Infrastructure for the Industrial Age", in ibid., pp. 55 - 106.

Io. Daniel Headrick, When Information Came of Age: Technologies of Knowledge in the Age of Reason and Revolution, I700-1859 (Oxford, 2002); Michael E. Hobart and Zachary S. Schiffman, Information Ages: Literacy, Numeracy, and the Computer Revolution (Baltimore, MD, 2000); Asa Briggs and Peter Burke, A Social History of the Media: From Gutenberg to the Internet (Oxford, 200I); Peter Burke, A Social History of Knowledge: From Gutenberg to Diderot (Cambridge, 2000).

Ir. Lewis Mumford, Technics and Civilization (San Diego, CA, 1934); Stephen Kern, The Culture of Time and Space: I880-19I8 (Cambridge, MA, I983). 
or, as geographers Jamie Peck and Adam Tickell describe it, "a commitment to the extension of markets and logics of competitiveness [combined] with a profound antipathy to all kinds of Keynesian and/or collectivist strategies". ${ }^{\text {I2 }}$ These governance strategies of privatization, "deregulation" (inevitably followed by reregulation), and market liberalization, when combined with global computer-mediated communications networks, may indeed herald a new form of "digital capitalism" as Dan Schiller has argued. ${ }^{13}$ Similar cases might be made for macro-processes of globalization, urbanization, and even, perhaps, democratization.

But others point out that, regardless of intervening forces, the IT revolution does not represent a fundamental change in the global capitalist economy. In the UK, geographers Ash Amin, Doreen Massey, and Nigel Thrift countered the government-sanctioned "Rogers Report" vision of twenty-first century informational cities by arguing that "the urban economic mainstream - in and beyond the knowledge economy - will continue to require traditional resources such as caterers, cleaners, tangible goods, part-time and seasonal work, and age-old means of communication". ${ }^{14}$ Even one of the most vocal advocates of recent IT in popular culture, cyberpunk novelist, Bruce Sterling, has viewed our current notions of living through "revolutionary" times as quaint: "The Radio Age, the Aviation Age, the Atomic Age, the Space Age [...] all of these socalled 'ages' are history. Soon our much-trumpeted 'Information Age' will have that same archaic ring", to the degree that "what is called new media would be better described as temporary media". Is If we can't even agree that our own times are revolutionary, how can we hope to make similar judgements about history?

\section{CONSIDERING THE PLACE OF LABOR IN IT REVOLUTIONS}

I think the greatest challenge in first periodizing, then describing, and finally analyzing information revolutions is that in the case of information technology, the moment of labor required for technological innovation has received the most attention, but the moments of labor dealing with technological production, distribution, and daily use have consistently been overlooked.

For example, historian of technology, Thomas Hughes, created a

I 2. Jamie Peck and Adam Tickell, "Neoliberalizing Space", Antipode, 34 (2002), pp. 380-404.

I3. Dan Schiller, Digital Capitalism: Networking the Global Market System (Cambridge, MA, 1999).

I4. Ash Amin, Doreen Massey, and Nigel Thrift, Cities for the Many, Not the Few (Bristol, 2000).

I 5. Bruce Sterling, "The Digital Revolution in Retrospect", Communications of the ACM, 40 (I997), p. 79. 
framework for understanding US technological history in particular by referring to entrepreneurial "system-builders" like Thomas Edison and Elmer Sperry: historical actors who combine engineering expertise with management insight to build profitable and pervasive technological infrastructures. ${ }^{16}$ In the twentieth century, such an explanation of historical change is often tied into the military-industrial-academic complex (the production of ENIAC, SAGE, and ARPANET come to mind). ${ }^{17}$ Even in the nineteenth century this framework can be deployed: one can explain the innovation of the telegraph by analyzing the systembuilding efforts of either individual entrepreneurs (Samuel Morse, Royal House, Alfred Bain) or corporate entities (Magnetic Telegraph, Western Union, AT\&T). Yet if one studies instead the labor of telegraph operators, one can see that important innovation took place on a daily basis in the space of the local office as well as in the space of the central electrical shop, not by professional engineers but by operators "on the key". ${ }^{18}$

Innovation does not only occur in the production of technology, however; often the consumers of technologies must innovate as well, especially business consumers who are using technology to gain a competitive edge in the capitalist marketplace. Here again, technology purchasers and managers are studied more readily than less powerful technology users, under a historical practice which turns its eye to the "visible hand" of corporate management under capitalism. ${ }^{19}$ This framework continues to be applied to a myriad of information technologies in the office workplace, both in the US and in Europe. ${ }^{20}$ But even the most well-executed "scientific office management" strategies rarely work as planned, and studies of those who labor under such systems can reveal the social innovations which often accompany technical ones. ${ }^{21}$ As Sharon Hartman Strom argued, "without an expanded army of clerks, managers, and business professionals, modern economic and government organization would have been impossible", since "an office hierarchy based on class and gender produced the paperwork, bookkeeping, and managerial

I6. Thomas P. Hughes, "Machines, Megamachines, and Systems", in Stephen H. Cutcliffe and Robert C. Post (eds), In Context: History and the History of Technology (Bethlehem, PA, 1989), pp. I06-II9.

17. Thomas P. Hughes, Rescuing Prometheus (New York, 1998).

I8. Paul Israel, From Machine Shop to Industrial Laboratory: Telegraphy and the Changing Context of American Invention, I830-1920 (Baltimore, MD, 1992).

19. Alfred D. Chandler, Jr, The Visible Hand: The Managerial Revolution in American Business (Cambridge, MA, 1977).

20. Richard L. Nolan, "Information Technology Management since 1960", in Chandler and Cortada, A Nation Transformed by Information, pp. 217-256; Onno de Wit, Jan van den Ende, Johan Schot, and Ellen van Oost, "Innovation Junctions: Office Technologies in The Netherlands, 1880-1980", Technology and Culture, 43 (2002), pp. 50-72.

21. William H. Leffingwell, Scientific Office Management (Chicago, IL, I917). 
expertise that propelled the machinery of scientific management and the integration of economic functions", a machinery and integration too easily ascribed to a management administrative revolution. ${ }^{22}$

Studies of how labor is involved in IT innovation illustrate an important point: it is the very ability of information technology to help us redefine the temporal and spatial parameters of our social existence that makes this kind of technology (and the times in which it exists) "revolutionary". We might think in terms of the "time-space distanciation" which Anthony Giddens has ascribed to modernity - the ability to act at a distance using formalized social and technical arrangements. ${ }^{23}$ Or we might consider the "time-space compression" which David Harvey has offered as a hallmark of postmodernity - the inability to act in isolation given the increasing spatial and temporal interdependence of different local sites, again through formalized political-economic and technical infrastructures. ${ }^{24}$ Either way, seeing IT revolutions as revolutions in social time and social space is a crucial (and productive) analytical strategy, revealing the production of a "fractured geography" that human and economic geographers have only begun to explore. ${ }^{25}$ But only when combined with the creative, productive, and ongoing presence of human labor (itself always situated in space and time) can information technologies - or, really, any technologies at all have such a transformative effect upon human society.

\section{DIFFERENT UNITS OF ANALYSIS WITHIN IT REVOLUTIONS}

One of the arguments I have tried to make in my own research is that the need to analyze the place of labor in this "revolution of time and space" is all the more pressing because labor is, almost by definition, the least obvious aspect of the information technology revolution to analyze. ${ }^{26}$ Simply put, labor is too often overshadowed by alternative units of analysis - the "information" or the "technology".

For example, ever since mathematical theorists Alan Turing, Claude Shannon, and Norbert Wiener operationalized concepts of "computability", "signal/noise", and "cybernetics" in the early twentieth century, the standard unit of analysis in IT revolutions has been taken to be

22. Sharon Hartman Strom, Beyond the Typewriter: Gender, Class, and the Origins of Modern American Office Work, 1900-1930 (Urbana, IL, I992).

23. Anthony Giddens, The Consequences of Modernity (Stanford, CA, 1990).

24. Harvey, Condition of Postmodernity.

25. James O. Wheeler, Yuko Aoyama, and Barney Warf (eds), Cities in the Telecommunications Age: The Fracturing of Geographies (New York, 2000).

26. Greg Downey, "Virtual Webs, Physical Technologies, and Hidden Workers: The Spaces of Labor in Information Internetworks", Technology and Culture, 42 (200I), pp. 209-235. 
"information". ${ }^{27}$ Indeed, although the "information science" of cybernetics has not proven to be the universal paradigm shift that its proponents once hoped, "information studies" has instead emerged to pursue the social concerns surrounding how information is organized and retrieved, commodified and consumed. Lively debates over electronic copyright, digital libraries, and online privacy may be found in this research stream. ${ }^{28}$ But while historians have followed social information through its life in "print culture", cultural-studies scholars are the ones primarily analyzing cyberspace as a hypertextual "virtual culture". ${ }^{29}$

How might labor be incorporated into such a focus? If the unit of analysis remains information itself, we might ask how information is brought to bear in the unequal relations between political-economic actors - not just the relationship between labor and capital, but competitive relations between individual laborers and cooperative relationships within labor organizing as well. Information in the form of propaganda and advertising has long been a tool by which capital has attempted to control its external environment, and information channels with labor are embodied both in corporate newsletters and factory reading rooms. ${ }^{3 \circ}$ As authors in the Journal of Labor Research and elsewhere have noted, labor's information exchange in the service of collective action faces both promises and risks in an environment of instantaneous but perhaps impersonal e-mail..$^{3}$ And since information about job openings is crucial to waged labor, as new IT infrastructures supplant personal word of mouth, new divides in the labor market may be opening. ${ }^{32}$ But while such issues are gaining the attention of sociologists, economists, geographers, and activists, synthesizing historical studies of these phenomena are hard to find.

27. Alan Turing, "On Computable Numbers, with an Application to the Entscheidungsproblem", Proceedings of the London Mathematical Society, series 2, 42 (1936-1937), pp. 230-265; Claude Shannon, "The Mathematical Theory of Communication", Bell System Technical Journal (July and October 1948); repr. in Claude Shannon and Warren Weaver, The Mathematical Theory of Communication (Urbana, IL, I949); Norbert Wiener, Cybernetics, or Control and Communication in the Animal and the Machine, 2nd edn (Cambridge, MA, I96I [1948]).

28. Lawrence Lessig, Code and Other Laws of Cyberspace (New York, 1999); Christine Borgman, From Gutenberg to the Global Information Infrastructure: Access to Information in the Networked World (Cambridge, MA, 2000).

29. Adrian Johns, The Nature of the Book: Print and Knowledge in the Making (Chicago, IL, 1998); James P. Danky and Wayne A. Wiegand (eds), Print Culture in a Diverse America (Urbana, IL, 1998); Steven G. Jones (ed.), Virtual Culture: Identity and Communication in Cybersociety (Thousand Oaks, CA, i997).

30. Stuart D. Brandes, American Welfare Capitalism, 1880-1940 (Chicago, IL, I976).

3I. Journal of Labor Research, special issue on IT and unions (Spring, 2002); Eric Lee, The Labour Movement and the Internet: The New Internationalism (London [etc.], 1997).

32. Susan Hanson, "Reconceptualizing Accessibility", in Donald G. Janelle and David C. Hodge (eds), Information, Place, and Cyberspace: Issues in Accessibility (New York, 2000), pp. $267-278$. 
Most recent historical studies of IT have, in fact, followed a different unit of analysis than information, echoing Marshall McLuhan's famous I964 declaration that "the medium is the message". ${ }^{33}$ Around this time, new "historians of technology" began to suspect that perhaps the proper unit of analysis in technological revolutions should be the technology itself. 34 Here the questions revolve around how technology is devised, commodified, and consumed in society; historical "household diffusion" and "social effects" studies, such as Claude Fischer's America Calling, are legion for any information technology we might identify, from the telephone and the radio to the television and the personal computer. ${ }^{35}$ In some places, such as the journal Technology and Culture, authors have uncovered fascinating cases where IT laborers have been hidden from the historical record. ${ }^{36}$ But too often with IT, studies still record only the actors of innovation and/or the actors of consumption, leaving laborers out entirely.

Here again, though, we could certainly incorporate labor into a technology-based focus. We might ask not who devises and markets information technologies, but who produces and reproduces them on a daily basis? What kind of service labor knits these technologies together into systems, networks, or even internetworks? And what kind of technical labor keeps increasingly complex technologies functioning on round-the-clock schedules? For example, the UK journal New Technology, Work, and Employment has in the last few years offered a forum for the discussion of IT and labor in contexts as diverse as welding, commercial broadcasting, and telephone call-centers. ${ }^{37}$ But adapting such sociological studies to historical contexts still proves elusive.

In each of these two ways of slicing the IT revolution - in terms of information or in terms of technology - labor lurks as a hidden unit of analysis. Information itself can be defined as the commodified surplus of centuries of labor. Technology has been alternately defined as the tool

33. Marshall McLuhan, Understanding Media: The Extensions of Man (New York, I964).

34. John Staudenmaier, Technology's Storytellers: Reweaving the Human Fabric (Cambridge, I985).

35. Claude S. Fischer, America Calling: A Social History of the Telephone to I940 (Berkeley, CA, I992).

36. Jennifer S. Light, "When Computers Were Women", Technology and Culture, 40 (1999), pp. 455-483; Richard Lindstrom, “They All Believe They Are Undiscovered Mary Pickfords": Workers, Photography, and Scientific Management”, Technology and Culture, 4I (2000), pp. $725-75 \mathrm{I}$.

37. A. Mutch, "The Impact of Information Technology on 'Traditional' Occupations: The Case of Welding”, New Technology, Work and Employment, I3 (1998), pp. I40-I49; A. McKinlay and B. Quinn, "Management, Technology and Work in Commercial Broadcasting, c.1979-98", New Technology, Work and Employment, I4 (1999), pp. 2-I7; V. Belt, R. Richardson, and J. Webster, "Women, Social Skill and Interactive Service Work in Telephone Call Centres", New Technology, Work and Employment, 17 (2002), pp. 20-34. 
of the skilled laborer, the engine behind the productive laborer, or the automation which should replace the expensive or intransigent laborer. And almost every historical periodization of the IT revolution has involved some sort of broad shift to "knowledge work", explicitly valorizing a certain set of (supposedly new) mental labors while relegating a parallel set of physical labors to the dustbin of history. Yet overall the notion of "information labor" as a historical unit of analysis is lacking any secondary synthesis or coherent body of theory.

\section{NORMATIVE ASSUMPTIONS ABOUT INFORMATION LABOR}

I won't pretend to offer such a synthesis here - that is a project not only beyond the scope of one article, but beyond the scope of one individual scholar. However, I would like to discuss some possible components of such a synthesis, because so many of the studies of IT labor which do exist are grounded in a priori (and often normative) assumptions which are only now coming under more nuanced scrutiny. These assumptions fall into three groups: assumptions about the productivity consequences of applying IT to manufacturing and services labor; assumptions about the characteristics of labor in industries which use IT to sell information itself; and assumptions about the spatial and temporal effects of IT-based production on society as a whole.

\section{Assumptions about IT and the productivity of labor}

First of all, like any technological change within a context of capitalist production, the goals of increased labor efficiency, productivity, and profitability have all been used to sell information technologies of all sorts. Yet in the specific case of IT, such quantitative gains may often come at a qualitative price. As Shoshana Zuboff argued after reviewing early-i980s IT investments in firms as diverse as paper mills and insurance offices, "Information technology not only produces action but also produces a voice that symbolically renders events, objects, and processes so that they become visible, knowable, and sharable in a new way", a process she called "informating" to indicate that it was the inevitable (and hopeful) flipside of "automating". ${ }^{8}$ But as more and more information becomes available about production processes - especially increased surveillance over the presumably unproductive activities of labor within those processes - a situation of "information overload" may occur, necessitating a vicious 
cycle of further IT investment in order to store, process, and make sense of the increased volume of surveillance data itself. 39

Another widely-popularized example of the risks of informating has been dubbed the "productivity paradox". Since new personal computers were viewed as "general purpose technologies" on par historically with the steam engine and electricity, economists in the early I980s expected large and easily-measurable productivity gains across nearly all aspects of the economy. But, in 1987, Morgan Stanley economist Steven Roach defined "America's technology dilemma" as increasing spending for IT coupled with flat productivity, and the race was on in academia to either explain or debunk this seeming paradox. ${ }^{4}$ Today the paradox is often declared solved by arguing that the "IT payoff" was merely delayed in its appearance: "As IT continues to displace labor, factory, and equipment throughout the production system [...] and IT investments approach io to is per cent of GDP, the economic contributions of IT will be more visible and the productivity issue will no longer be a matter of debate." ${ }^{4}$

Both the debates over "information overload" and "productivity paradoxes" are contested in terms of theory, measurement, and normative focus (overload for whom? productivity of whom?). But each case, expectations of the corporate benefit from IT are structured by competition, as capital collectively adopts a new "socially necessary" set of labor processes. New IT is bound up with images of progress, success, and power such that for both organizations and individuals, the question is no longer whether to use IT in the workplace, but how best to use IT for both organizational and personal goals. Yet such choices are not automatic for historical actors - economists have long observed that under changing spatial and temporal conditions of competition, firms may display “industrial rigidity". Economic geographer, Erica Schoenberger, has studied how such coping strategies are formed, linking corporate actions to the self-identities (and firm-identities) of high-level decision makers themselves. Using case studies from Lockheed and Xerox, she argued that managers don't resist all forms of change, but are constrained in the kinds of change they will attempt or accept. ${ }^{42}$ Thus as historians we might ask: is such a pattern of "inevitable" but constrained IT adoption, filtered through the eyes of actors trying to both envision new strategies and

39. Andrew Urbaczewski and Leonard M. Jessup, "Internet Abuse in the Workplace: Does Electronic Monitoring of Employee Internet Usage Work?", Communications of the ACM, 45:I (2002), pp. 80-83.

40. Erik Brynjolfsson and Lorin M. Hitt, "Beyond the Productivity Paradox", Communications of the ACM, 41:8 (1998), pp. 49-55.

4I. Sanjeen Dewan and Kenneth L. Kraemer, "International Dimensions of the Productivity Paradox", Communications of the ACM, 41:8 (1998), pp. 56-62.

42. Erica Schoenberger, The Cultural Crisis of the Firm (Cambridge, MA, 1997). 
measure current risks, found consistently in capitalist economies whenever the space/time "rules of the game" change due to new technology?

If historical assumptions about the productivity of new workplace technologies have been overly optimistic, then perhaps they are balanced by pessimistic assumptions about the elimination of labor altogether due to that same technology. For example, in the US, worries over wholesale "deindustrialization" after the oil price shocks of 1973 and I 979 quickly followed the original enthusiasm over the "postindustrial" society, especially given the dramatic loss of profitability in the US auto industry and the equally dramatic governmental attacks on organized labor in the 1980s. ${ }^{43}$ Information technology, along with the new globalization which it seemed to be enabling, was one of the culprits in this analysis. According to one estimate, in 1970 there were under 1,000 industrial robots in operation worldwide, but only a decade later there were more than 30,000.44 This situation led social critics Stanley Aronowitz and William DiFazio to predict a "jobless future" in I 994 and Jeremy Rifkin to declare that "the end of work" was near in I 995.45 For the editor of CPU: Working for the Computer Industry, the idea that "latter-day capitalism asymptotically approaches 'laborless production", was self-evident in the new "dark factories": fully-automated factories so named because the interior lights were left turned off, since there were no humans present inside. ${ }^{46}$

As historians, we first need to remember that such debates are not new. Amy Bix has effectively shown that questions over technological job loss have waxed and waned throughout the twentieth century, especially during hard economic times: "During the Depression decade, I930 to I940, many citizens worried that stubbornly high unemployment rates signified a deep imbalance in the Machine Age system." 47 In this context, Elizabeth Baker first documented " $t]$ he displacement of men by machines" in the printing industry (1933). ${ }^{8}$ Second, historical precedent shows that job loss is not necessarily the only result of new technology (if it is a result at all). Stuart Blumin reminded us that

43. Barry Bluestone and Bennett Harrison, The Deindustrialization of America: Plant Closings, Community Abandonment, and the Dismantling of Basic Industry (New York, 1982).

44. Tessa Morris-Suzuki, "Robots and Capitalism", in James Davis, Thomas Hirschl, and Michael Stack (eds), Cutting Edge: Technology, Information Capitalism, Social Revolution (London, 2000), pp. I $3-28$.

45. Stanley Aronowitz and William DiFazio, The Jobless Future: Sci-Tech and the Dogma of Work (Minneapolis, MN, 1994); Jeremy Rifkin, The End of Work: The Decline of the Global Labor Force and the Dawn of the Post-Market Era (New York, 1995).

46. Jim Davis and Michael Stack, "The Digital Advantage", in Davis, Hirschl, and Stack, Cutting Edge, pp. I 2 I-I 44 .

47. Amy Sue Bix, Inventing Ourselves Out of Jobs? America's Debate over Technological Unemployment, 1929-198I (Baltimore, MD, 2000).

48. Elizabeth Faulkner Baker, Displacement of Men by Machines: Effects of Technological Change in Commercial Printing (New York, 1933). 
The number of office workers (bookkeepers, cashiers, accountants, office clerks, stenographers, and typists) increased ninefold in the last thirty years of the [nineteenth] century, from fewer than 70,000 to more than 600,000 , and, though fully one-third of this increase is accounted for by the entrance of women into all types of clerical office work, $[. .$.$] the multiple increase for men was nearly three$ times as great as the multiple for the male work force as a whole. 49

In seeking meaningful patterns of historical change, we may find it most useful to trace not aggregate job losses or gains, but a more subtle shift from higher-wage manufacturing jobs to lower-wage service jobs - many with an information-processing component or context. This "contingent economy" has grown together with the rise of office IT, yet cannot be reduced to that IT (especially in light of overt neoliberal state policies which encourage such an economy). ${ }^{\circ}$ For example, a recent review of the division of labor in the US construction industry concluded that "Introduction of computer technology in the past two decades has occurred concurrently with a 40 per cent reduction of support staff as a percentage of total construction employment, and a doubling of management as a fraction of the construction work force", although "[t]he fraction engaged in craftwork has remained relatively stable". sI Here again, attending to changing divisions of labor - technical, social, and spatial/temporal divisions which embody both obvious industrial restructuring together with more subtle shifts in responsibility, status, and career security - is a useful analytical strategy.

Somewhere between debates over increased productivity or increased unemployment are the questions over the effects of technology on the aggregate skill level (and, according to neoclassical economics, the justifiable wage level) of labor. Much of this debate came in the I980s as a response to Harry Braverman's early i970s “degradation thesis" that shifts into service occupations didn't necessarily mean greater skills, better wages, or less tedium..$^{2}$ His arguments drew upon a history of Taylorist "scientific management" which recognized that if nothing else, the hyperrationalized management systems of Taylor, Ford, and others were information technologies themselves. ${ }^{3}$ By the early I990s, more optimis-

49. Stuart Blumin, "The Hypothesis of Middle-Class Formation in Nineteenth-Century America: A Critique and Some Proposals", American Historical Review, 90 (1985), pp. 299-338. 50. Richard S. Belous, The Contingent Economy: The Growth of the Temporary, Part-Time and Subcontracted Workforce (Washington DC, 1989); Polly Callaghan and Heidi Hartmann (eds), Contingent Work: American Employment Relations in Transition (Ithaca, NY, 1998).

5. James W. Platner and Xiuwen Dong, "Impacts of Digital Information Networks on Construction Contractors and Unions", Journal of Labor Research, 23 (2002), pp. 575-590, 588. 52. Harry Braverman, Labor and Monopoly Capital: The Degradation of Work in the Twentieth Century (New York, 1974).

53. Robert Kanigel, The One Best Way: Frederick Winslow Taylor and the Enigma of Efficiency (New York, 1997). 
tic analysts like Paul Adler had swung away from Braverman's deskilling thesis to a new upgrading thesis:

There are, of course, some cases where deskilling occurs. But an emerging body of research suggests first, that the use of new technologies will in general be more profitable when entrusted to more highly skilled employees, and second, that as a result, firms generally, although not always, "muddle through" to an implementation approach premised on upgraded skills and broader jobs. ${ }^{54}$

Like the questions over productivity and job loss, the deskilling/ upgrading debate was mainly argued in terms of manufacturing automation and the twin concepts of deindustrialization and postindustrialization. But the issue was also applied to office automation, though measuring this has been notoriously difficult. One early I 990 s study in the US, using midI980s data, argued that employees who used computers at work were paid up to is per cent more than those who didn't.5s A more recent US study claimed to support these findings, now citing Internet use at work (rather than plain old computer use) as the factor motivating an average wage difference of 13.5 per cent. ${ }^{56}$

But instead of looking simply at deskilling or upgrading, perhaps the place to look for historical change is in the contextual redefinition of skills themselves (and of the status associated with those skills). For example, there has been much debate over the existence of "digital divides" between those who have access to IT and those who do not, not only on a global scale but even within affluent states such as the US. ${ }^{57}$ Usually digital divides are defined at the scale of the individual household or the individual school district; but defining them at the scale of the workplace as well might offer a new way for historians to unpack the meaning of "skill" together with other aspects of labor conditions, especially the ability to weave one's roles as consumer, citizen, and family member together with the role of worker. ${ }^{8}$ Interestingly, Braverman's 1974 work was already beginning to wrestle with such combined redivisions of labor:

[...] the employment of machinery pushes the office installation toward the warehouse and industrial districts of the cities. This is facilitated by the development of remote terminals and other communications devices which

54. Paul S. Adler (ed.), Technology and the Future of Work (New York, I992), p. 3.

55. Alan Krueger, "How Computers Have Changed the Wage Structure: Evidence from Microdata, 1984-1989", Quarterly Journal of Economics, 108 (1993), pp. 33-60.

56. Ernest P. Goss and Joseph M. Phillips, "How Information Technology Affects Wages: Evidence Using Internet Usage as a Proxy for IT Skills”, Journal of Labor Research, 23 (2002), pp. $463-475$.

57. Pippa Norris, Digital Divide: Civic Engagement, Information Poverty, and the Internet Worldwide (Cambridge, 200I).

58. Greg Downey, "Differing Views of the Digital Divide: Social Justice and Spatial Justice in Cyberspace”, in progress. 
annihilate distance and do away with almost all the inconveniences of separate installations, so that executive offices can be maintained in the more expensive and accessible locations while the mass of clerical workers can be moved into lower-rent districts, often together with warehousing or production facilities. Thus the convenience and cachet of working in the central part of town, with its greater shopping interest and more varied lunching facilities, etc., begins for many clerical workers to disappear. 59

This linking of new divisions of production with new divisions of social reproduction is another crucial strategy for tracing the information age historically.

\section{Assumptions about labor in the information industries}

Within the (often internalist) historical study of particular information industries, we can trace a second set of normative assumptions, this time concerning the workers rather than the work performed. The first of these assumptions dates back to the late nineteenthth century, when the first electrically-powered infrastructures for communication were consolidated under increasingly vast and increasingly centralized corporate structures: railroads, telegraphs, and telephones. These new networks of rails, wires, and offices, requiring such visible investments in the built environment, were subject to a pair of intertwined assumptions. First, the presence of these infrastructures was deemed a collective social good - just as postal delivery was seen as a fundamental component of republican democracy, so would rail access and wired communication be thought of as essential components of social and economic participation in the nation, regardless of the differing level of profit which firms might extract from one site versus another. ${ }^{60}$ Second, the redundant construction of these infrastructures by different firms in the same place was seen as wasteful of social resources, an example of "ruinous competition" which detracted from the goal of "universal service". Out of these two sentiments came the idea that information infrastructure industries were somehow "natural monopolies”, best organized under centralized control and subject to specific regulation for the social good. ${ }^{61}$

In such a realm of monopoly information infrastructures, laborers were often seen as technological components subject to a similar kind of regulation and rationalization - an ideal which affected organizing efforts in the telegraph and telephone industries even across differences of race,

59. Braverman, Labor and Monopoly Capital, p. 353.

60. Richard R. John, Spreading the News: The American Postal System from Franklin to Morse (Cambridge, MA, I995).

6I. This pattern worked out a bit differently in the US, where private interests such as Western Union and AT\&T were allowed to reap profit from communications monopolies; nevertheless, they were theoretically subject to state regulation. 
gender, and age. ${ }^{62}$ Issues of national security and government accountability worked their way into communications industry labor battles across national contexts; as a result, in most places these information jobs were part of a civil service, though in the US they evolved through successive periods of "benefit associations", company unions, and finally independent labor unions. For example, even though it took the lowly messenger boys (a historical archetype of contingent, piecewage labor) nearly a century to be folded into the US telegraph unions, the timing of that recognition was profoundly affected by the timing of two world wars - and by the telegraph's strategic importance in both. ${ }^{63}$

In contrast, the case in the growing media industries over the same period - not only print, but later radio and television - was one of more varied constructions of labor. On one hand, these industries required traditional industrial labor in order to function - paper had to be milled, printing presses had to roll, resistors and vacuum tubes had to be soldered into consumer radios and television sets. Such activities, some unionized and some not, were generally not seen as "information labor" - however, they could valuably be analyzed as such, especially as these extractive and manufacturing jobs were among the first to be marched across both regional and national borders. ${ }^{64}$ On the other hand, the creative talent behind the growing mass media - writers and actors, advertisers and musicians - was often considered a professional and independent elite, not a category of "labor" at all. Owning their own typewriters, finding their own clients, submitting their own work over and over again for payment by the piece, these individuals were often seen as entrepreneurs, even down to the newsboys who "purchased" papers from distributors in the morning and "resold" them for pennies on the dollar well into the night. ${ }^{65}$ Jeremy Tunstall noted that the media professions have for at least a century been associated with a "moral division of labor", whether embodied in the distinction between respectable vs. bawdy theater, family vs. adult filmmaking, or serious vs. sensational journalism (with all of those normative definitions subject to contemporary debate and historical change). Significantly, even by 1900 , this moral division of labor was profoundly structured by space and time (in North American and European cities at least): "Larger cities already had their distinctive theater

62. Edwin Gabler, The American Telegrapher: A Social History, I860-I900 (New Brunswick, NJ, 1988); Venus Green, "Race, Gender, and National Identity in the American and British Telephone Industries", International Review of Social History, 46 (200I), pp. I85-205.

63. Greg Downey, Telegraph Messenger Boys: Labor, Technology, and Geography, I850-1950 (New York, 2002).

64. Jefferson Cowie, Capital Moves: RCA's 70-Year Quest for Cheap Labor (Ithaca, NY, 1999). 65. Vincent R. DiGirolamo, "Crying the News: Children, Street Work, and the American Press, I830s-I920s”, (unpublished Ph.D. thesis, Princeton University, NJ, I997). 
and newspaper districts, whose employees typically worked at unusual times (especially in the evening) and tended to intermix socially; in these fairly insecure and irregular types of employment, social life also became a network for finding work." "T6 This moral and spatial division of labor was also a gendered division of labor, a characteristic which persisted into media broadcasting on radio and TV. ${ }^{67}$

Various moral, spatial, and gender divisions of labor persist in the "media monopolies" of today, under new conditions of digital and economic convergence. ${ }^{68}$ While new technology and new neoliberal policies affect media landscapes around the globe, their effects are by no means homogenous over this differentiated geography. For example, Ellen Hazelkorn's study of changes in the occupational structure of Ireland's television industry highlighted the special case of a smaller-population European country with a strong public broadcaster of its own competing with a powerful set of neighboring international broadcasters (BBC and ITV). ${ }^{69}$ The more varied environments we can find for such studies especially the formerly state-controlled media spheres of eastern Europe the better we might understand how the laborers within media production systems are both constrained by and help set the limits of national media norms and practices. ${ }^{70}$

Although the communication infrastructure and media content industries are sometimes considered sites of "information labor" by scholars, the education industries rarely are. This is partly because education tends to be state-funded rather than market-based (though current neoliberal state policies aim to change this). But another reason can be found in the historical division of labor in the education industries. In the US, a polarization exists between primary/secondary education and college/ university education. At the grade levels, education labor is highly unionized, highly feminized, and (arguably) undervalued both economically and socially; at the college levels, education labor is rarely unionized, more gender balanced, and contradictorily valued with large research universities both charging high tuition fees and maintaining a culture in which education is secondary to publication in terms of hiring and

66. Jeremy Tunstall (ed.), Media Occupations and Professions: A Reader (New York, 200I), p. 2. 67. Donna L. Halper, Invisible Stars: A Social History of Women in American Broadcasting (Armonk, NY, 200I).

68. Robert W. McChesney, Ellen Meiksins Wood, and John Bellamy Foster (eds), Capitalism and the Information Age: The Political Economy of the Global Communication Revolution (New York, 1998).

69. Ellen Hazelkorn, "New Technologies and Changing Work Practices in Irish broadcasting", in Tunstall, Media Occupations and Professions, pp. 214-226.

70. Julie Kay Mueller, "Staffing Newspapers and Training Journalists in Early Soviet Russia", Journal of Social History, 3I (I998), pp. 85 I-874. 
retaining faculty. As a result, questions over the proper place of new IT in each realm lack any connection to each other..$^{71}$ Furthermore, the tricky realm of technical/vocational education - where two-year training as a "Microsoft-certified network technician" might be more valuable than a liberal arts education - fits neither of these stereotypes. Here, many of the institutions are for-profit entities, and most of the content is overtly related to the long-standing aim of labor to find high-wage, high-tech careers (and of capital to externalize its own training costs). ${ }^{72}$ Libraries offer a third set of sites where educational information management takes place in society, historically in a highly gendered division of labor. ${ }^{73}$ Again, although today the notion of digital libraries is bringing some of this labor more into focus (often within the same debates of productivity, job loss, and deskilling as described earlier), we should not forget that the creation and honing of card- and shelf-based cataloging systems a century ago were no less valid forms of information work. ${ }^{74}$

Finally, a fourth category of information industry developed with the increasing bureaucratization and rationalization of the capitalist firm (and the state administrative unit) through the nineteenth and twentieth centuries: office work. This is one area in which not only historians but sociologists have made numerous contributions, tracing a history from the "Victorian clerks" in the nineteenth century to the legions of "whitecollar" workers in the twentieth.75 Much of this work has been motivated by three theoretical imperatives: attempting to define the "middle class" through the shift to office-based, symbol-processing service labor; tracing the polarization between professional white-collar workers and clerical white-collar workers (with that middle class being divided starkly along lines of power, wages, and tasks); and attempting to understand the way gender, race, and ethnicity are involved in these labor polarizations especially how white-collar work becomes feminized into "pink-collar"

71. Larry Cuban, Oversold and Underused: Computers in the Classroom (Cambridge, MA, 200I).

72. Nina E. Lerman, “From 'Useful Knowledge' to 'Habits of Industry': Gender, Race, and Class in Nineteenth-Century Technical Education" (unpublished Ph.D. thesis, University of Pennsylvania, 1993); B.P. Cronin, Technology, Industrial Conflict, and the Development of Technical Education in Igth-Century England (Aldershot [etc.], 200I).

73. Dee Garrison, "The Tender Technicians: The Feminization of Public Librarianship, I876I905", Journal of Social History, 6 (1973), pp. I3 I-I 59; Joanne Passet, "Men in a Feminized Profession: The Male Librarian, 1887-1921", Libraries E Culture, 28 (1993), pp. 385-402.

74. Borgman, From Gutenberg to the Global Information Infrastructure; Wayne A. Wiegand, The Politics of an Emerging Profession: The American Library Association, 1876-1917 (Westport, CT, 1986).

75. Gregory Anderson, Victorian Clerks (Manchester, 1976); Jürgen Kocka, White Collar Workers in America, I 890-1940: A Social-Political History in International Perspective, trans. by Maura Kealey (London, I980). 
work. ${ }^{76}$ Even environmental history, as it has moved from the study of outdoor recreation spaces to indoor work places, has profited from the key insight that office labor history is structured by power and gender. ${ }^{77}$

\section{Assumptions about IT and the space and time of the production process}

In Alvin Toffler's 1980 manifesto The Third Wave (a sequel to his 1970 Future Shock) he spoke of the way computer-mediated communications would enable the rise of "electronic cottages" - a metaphor meant not only to evoke the unproblematic high-tech wiring of the sylvan, suburban home, but also to draw upon the idea of "cottage industry" where petty capitalists carved careers based on various information skills, selling those skills on a virtual market while avoiding long commutes and watching the kids at home. ${ }^{78}$ Clearly, such a scene has not come to pass; however, with twenty years of intervening technological innovations such as cell phones and laptop computers, the focus of the wired household has arguably shifted to that of the wired individual (or in the US, perhaps, the wired sport utility vehicle). We have neither escaped our long commutes nor nested in our safe homes; however, with technology actually attached to the body, we have fragmented our daily existence so that the "separate spheres" of work and home blur together. An original vision of "telecommuting" as our new labor norm has been replaced with a more flexible vision of "teleworking".

Of course, the "we" here provides the key question. Put aside the statistics on digital divides which show that in the US, for example, even in 2002 only around 50 per cent of all households reported having Internet access. 79 Even within privileged "wired" households, which persons are able to fragment their work in space and time, from paper to bits, away from the congeniality of colleagues but still under the watchful eye of management? Empirical studies have found polarizations - highly-paid purveyors of business services go "hoteling" from office to client to home

76. C. Wright Mills, White Collar: The American Middle Classes (New York, I95 I); Rosabeth Moss Kanter, Men and Women of the Corporation (New York, I977); Heidi I. Hartmann (ed.), Computer Chips and Paper Clips: Technology and Women's Employment, vols I-2, (Washington DC, 1987); Francisca Maria de Haan, Gender and the Politics of Office Work: The Netherlands I860-1940 (Amsterdam, I998).

77. M. Murphy, "Toxicity in the Details: The History of the Women's Office Worker Movement and Occupational Health in the Late-Capitalist Office”, Labor History, 4I (2000), pp. I89-2I3.

78. Alvin Toffler, The Third Wave (New York, I98 I); Langdon Winner, "Whatever Happened to the Electronic Cottage?”, Netfuture \#, I 2 I [www.netfuture.org] (200I).

79. US Department of Commerce, National Telecommunications and Information Administration, A Nation Online: How Americans are Expanding Their Use of the Internet (Washington DC, 2002). 
to hotel and back again, always in touch; struggling home entrepreneurs plug their business plans into both virtual broadband Internet subscriptions and local Mail Boxes Etc. shipping addresses; and most of all, lowpaid data-entry workers use century-old typing or stenography skills to translate information from printed forms to computer screens, from tape recorders to text files, sometimes out in the next suburb and sometimes halfway around the world. ${ }^{80}$ In too many cases, and in ways structured by the same old categories of gender, age, ethnicity, language, and family status, the virtual worker of tomorrow looks more and more like the piecewage homeworker of yesterday. ${ }^{8 \mathrm{I}}$

Speculations about the space/time fragmentation of labor do not always start with the laborer, however. They also start with the firm itself. Especially in America, characterizing the days of US dominance over the global manufacturing market as over, the business press urges entrepreneurs and managers to make their firms more "agile", their work teams more "flexible", their responses to market conditions executable "just in time". ${ }^{82}$ A whole field of study has arisen under these normative assumptions, combining the disciplines of organizational psychology and computer science to build the best performing systems for "distributed work" - an ideal situation where individual professionals, all of equal status and equal motivation, participate in global "teams" which are constantly shifting in size and composition. ${ }^{83}$ Though the term "distributed" suggests that space is the most important consideration, it is really time that matters - turnover time in assembling teams, executing effective business plans, and then just as quickly disassembling teams (avoiding the pesky time scales of vacations, promotions and pensions).

These intertwined visions of the proper model for the individual and the corporation in the new economy (or, we could argue, the neoliberal political economy) come together in predictions of the changes which will accrue in social space itself as these models are increasingly instantiated. The old notions of cities withering into garden communities have been abandoned for a more Darwinian model: entrepreneurial cities which become "wired" - not only by investing in electronic infrastructure, but by attracting the "right" sorts of workers and venture capitalists - will transcend the limits of their states to become "cities of bits", linked into the

80. C. Stanworth, "Telework and the Information Age", New Technology, Work and Employment I3:I (1998), pp. 5 1-62; Carla Freeman, High Tech and High Heels in the Global Economy: Women, Work, and Pink-Collar Identities in the Caribbean (Durham, NC, 2000).

8r. Eileen Boris and Cynthia R. Daniels (eds), Homework: Historical and Contemporary Perspectives on Paid Labor at Home (Urbana, IL, I989).

82. N. Fredric Crandall and Marc J. Wallace, Work and Rewards in the Virtual Workplace: A "New Deal" for Organizations and Employees (New York, 1998).

83. Pamela Hinds and Sara Kiesler (eds), Distributed Work (Cambridge, MA, 2002). 
global networks of information, capital, and spectacle. ${ }^{84}$ On the other hand, cities which don't (or can't) become wired will be left to fight for the scraps of the old economy under conditions of increasing state support, shrinking tax bases, declining services, and decaying infrastructure. ${ }^{85}$ Sadly, both models abandon an earlier definition of wired cities, drawn from the promise of interactive cable television in the late 1960s, which envisioned such places as mustering information technology - and labor for the social good of all. ${ }^{86}$

Besides their normative (and often ahistorical) assumptions about the proper models for individuals, organizations, and urban areas, the biggest problem with these three separate theories is that the spatial scales of the household, the firm, and the city interact dialectically with any social process we might investigate - not just production, but consumption and reproduction as well. ${ }^{87}$ When "big-box" retail stores like Wal-Mart enter new markets, they do more than shift the spatial division of consumption from main streets; they shift a spatial division of labor from other employment opportunities and they shift a spatial division of capital out of the community. Such stores are increasingly involved in e-commerce in two ways: first, they require massive investments in information infrastructures to coordinate the tension between large-scale purchasing power (which drives costs down and profits up, taking market share from resellers who can't purchase as much or as quickly) and local fragmented consumption (channeling products to specific stores in specific places for specific consumer groups, restocking shelves "just in time"); second, they often involve a web presence which leverages the physical network of store sites as generators of local print and broadcast advertising, sites for "pickup" stock to avoid shipping costs, and sites for merchandise return consumption processes which, when handled in a physical site and not through the mail, may spin off into additional impulse sales. Thus should we consider the service labor upon which these stores rely as "information labor"? Should we be concerned about labor organizing efforts in rural strip malls as well as in Silicon Valley? If so, we should apply these same ideas to the previous turn-of-the-century, and reconsider the labor implicated in the then high-tech catalog retailing ventures of, in the US

84. David Harvey, "From Managerialism to Entrepreneurialism: The Transformation in Urban Governance in Late Capitalism”, Geografiska Annaler, 71:B (1989), pp. 3-17; William J. Mitchell, City of Bits: Space, Place, and the Infobabn (Cambridge, MA, I995).

85. Joel Kotkin, The New Geography: How the Digital Revolution Is Reshaping the American Landscape (New York, 2000).

86. Ralph Lee Smith, The Wired Nation: Cable TV, the Electronic Communications Highway (New York, I972); William H. Dutton, Jay G. Blumler and Kenneth L. Kraemer (eds), Wired Cities: Shaping the Future of Communications (Boston, MA, 1987).

87. Neil Wrigley and Michelle Lowe, Reading Retail: A Geographical Perspective on Retailing and Consumption Spaces (New York, 2002). 
case, Sears and Wards as a sort of "informational labor" as well, iterated not over the web but through the printing presses, postal roads and telephone lines.

Such issues are finally gaining attention with the recent push to synthesize the relationships between IT, the city, and social processes. ${ }^{88}$ Urban planning scholar, Laura Wolf-Powers, recently pointed out that

In advanced urban economies, scholars and policymakers argue, measures conventionally pursued to attract firms - tax incentives, urban infrastructure, mega-projects focused on drawing tourists or convention-goers - are increasingly less effective, because human capital, not physical capital, has become the twenty-first century's key competitive advantage. Thus, policies to attract desirable workers, in addition to policies aimed at increasing the skill level of the existing workforce, have gained priority among economic development planners."

But she pointed out a crucial flaw in this "community-upskilling" logic: "the majority of new jobs created in the 'knowledge economy' will continue to be low-status and low-paid". ${ }^{89}$ In analyzing these relationships, many still argue simply that "Networked computing deterritorializes labor, rendering irrelevant the location on Earth of the work being done", and "retemporalizes labor by introducing a register of instantaneousness that is comprehensible as computer time but not as human or even machine time". ${ }^{\circ}$ If we are to decide whether or not IT can "deterritorialize" labor completely, then attention to territory is precisely what is needed most.

What links each of these differing normative frameworks - involving assumptions about productivity and job loss, industrial and occupational character, and spatial/temporal reorganization of production - is that they all suggest that a universal, natural trend of technological development is somehow at work in the economy (and in society). Technology will inevitably trivialize labor; information industries will inevitably embody certain kinds of employment relations; and information labor of all sorts will inevitably decentralize throughout society. Thus what these frameworks all share more than anything else is a thread of technological determinism.

The idea of technological determinism doesn't have to be expressed as starkly as a teleological "progress narrative" of continually increasing mechanization, automation, and informatization to which society must

88. Stephen Graham and Simon Marvin, Splintering Urbanism: Networked Infrastructures, Technological Mobilities and the Urban Condition (London, 2001).

89. Laura Wolf-Powers, "Information Technology and Urban Labor Markets in the United States", International Journal of Urban and Regional Research, 25 (200I), pp. 427-438, 428. 90. Mark Poster, "Workers as Cyborgs: Labor and Networked Computers", Journal of Labor Research, 23 (2002), pp. 339-354, 340. 
inevitably adapt. Instead, we as historians implicitly draw upon technological determinism when we are unable (or unwilling) to explore how diverse historical actors - not just the producers of technology, not even just the consumers of technology, but also those who reproduce that technology on a daily basis - made their many different choices to embrace, accept, ignore, or contest those technologies. At times we seem to assume that labor history is a socially constructed history, but technological history is a materially determined one.

Fortunately, recent history of technology research contradicts this idea, with the most fruitful and provocative work taking the position that technology operates dialectically in society: both a product of human thought and action, and a powerful structural force enabling and constraining human thought and action. ${ }^{9 \mathrm{I}}$ From the point of view of labor, processes of work are inevitably mediated by technologies, whether those technologies are defined in the classical dichotomy between "tools" and "machines" (each of those carrying normative assumptions about the enskilling and deskilling of labor) or whether technologies are defined more abstractly as "knowledges" and "systems" (where efforts to turn human skills and experience into Taylorist algorithms are themselves powerful technologies). From the point of view of technologies, dialectical processes of technological innovation, production, distribution, and daily use all depend on human labor, though each stage involves different kinds of labor from different groups of actors in different proportions (and often resulting in differing rewards). Over a decade ago, Phil Scranton argued for closer cooperation between historians of labor and historians of technology. However, Scranton specifically called for more study of "efforts to discern the relationships between shop-floor practice and technical change in American industry", rather than, among other topics, studies of information labor..$^{22}$ Filling this gap is even more important today.

\section{THE INVISIBILITY OF INFORMATION LABOR}

After reviewing this (partial) historiography of how information technologies and practices have been linked to labor so far, we need to ask at this point: why is the labor history of the information revolution such an elusive topic even to find, let alone to synthesize? Is it because information labor, unlike other forms of labor, is somehow "invisible?". Is it because information labor, even when recognized as such, does not involve the exploitation of a working class? Or is it because information labor, even

9I. Merritt Roe Smith, “Technological Determinism in American Culture”, in Merritt Roe Smith and Leo Marx (eds), Does Technology Drive History? The Dilemma of Technological Determinism (Cambridge, MA, I994), pp. I-36.

92. Philip Scranton, "None-Too-Porous Boundaries: Labor History and the History of Technology”, Technology and Culture, 29 (1988), pp. 722-743. 
when involving uneven and unjust social relations, has neglected to understand itself as labor and to organize collectively?

First, consider the many kinds of "invisibility" which we wrestle with in labor history. The Marxian concept of "commodity fetishism" has long suggested that all labor retains a degree of invisibility under capitalism, since all a consumer ever witnesses is a commodity's final, momentary price. All sorts of unwaged labor, especially by women, have also been invisible to the workings of the capitalist market (treated as "household reproduction" or "economic externalities").93 Sociologist, Erving Goffman, has referred to the difference between "front-stage" and "back-stage" social processes, and most information labor may be contained in that back-stage space as workers seek out, assemble, and organize information out of view of peers, managers, or customers. ${ }^{94}$ Historian of science, Steven Shapin, has pointed to the invisibility of low-status technical labor in the production of scientific knowledge. ${ }^{95}$ And management's desire to formalize and rationalize labor processes has always been balanced by the fact that some work inevitably and invisibly escapes systematization, an idea which has gained currency again as work has been distributed in space and time due to information technology. ${ }^{96}$

Information technology adds another degree of invisibility to the mix. The virtual characteristics of the "information commodity" itself may help to obscure the labor necessary in its production - especially when those information commodities are apparently stored, located, duplicated, and exchanged (in the case of Napster, some might say stolen) so quickly and effortlessly from the vantage point of the consumer. ${ }^{97}$ At the former Xerox Palo Alto Research Center - arguably the birthplace of the modern officetechnology environment - one researcher regretted that "work has a tendency to disappear at a distance, such that the further removed we are from the work of others, the more simplified, often stereotyped, our view of their work becomes".$^{9}$ If we value the history of this work, we must help these workers to reappear.

But even when made visible, information labor is sometimes not even accorded the status of "labor" - at least labor of a certain kind. An actor in the informational society theorized by Manuel Castells is either privileged

93. Ruth Schwartz Cowan, More Work For Mother: The Ironies of Household Technology from the Open Hearth to the Microwave (New York, 1983).

94. Erving Goffman, The Presentation of Self in Everyday Life (London, I969).

95. Steven Shapin, "The Invisible Technician", American Scientist, 7 (1989), pp. 554-563.

96. Susan Leigh Star and Anselm Strauss, "Layers of Silence, Arenas of Voice: The Ecology of Visible and Invisible Work”, Computer Supported Cooperative Work, 8 (1999), pp. 9-30.

97. Dan Schiller, "The Information Commodity: A Preliminary View", in Davis, Hirschl, and Stack, Cutting Edge, pp. 103-I 20.

98. Lucy Suchman, "Representations of Work: Making Work Visible", Communications of the $A C M, 38: 9$ (1995), pp. 56-68. 
to be in the space of flows (as an individual, an entrepreneur, a city, or a region) or is placed on the other side of the "dual city" in a "black hole of the information economy" (where the standard labor history of industrial and service exploitation still applies). ${ }^{99}$ Yet sociologists of work have called such stark dualities into question. While not denying that polarizations of income, status, and career prospects are being produced, they nevertheless argue that many new technology tasks, jobs, and careers blur any polarizing categories. For example, Peter Whalley and Stephen Barley argued that "technical work" (such as computer-support labor) transcends two common dichotomies: first, it involves both "mental" and "manual" labors simultaneously; second, it is both occupationally structured (worker as independent craftworker or professional) and organizationally structured (worker as bureaucratic company employee) at the same time. ${ }^{100}$ In this way, information labor might be recognized as actually serving an important mediating role between other more homogenous organizational and occupational groups.

Even if information labor is made visible as such, the assumption that information laborers do not take collective action could be a barrier to critical analysis of their history. Perhaps the best example of this difficulty in recent years has been the question of the relationship between IT and trade unions. In the US, for example, overall union membership has declined dramatically under conditions of neoliberal governance, economic restructuring, and capitalist globalization just as personal computers, personal communications, and the World Wide Web have all entered the workplace. One group of management information systems researchers recently argued that,

Information technologies make knowledge and information into a transportable commodity, which in turn transforms an organization from a factory into a body of ideas and skills. The "real" firm no longer exists in its machinery and production space, but in the knowledge and information systems that enable production. Thus, there is no factory to organize, no critical assembly line to strike, no organizational lynchpin on which a union can apply effective leverage. ${ }^{\text {IOI }}$

Although finding causal links is problematic, there is clearly a need to connect projects dealing with the "new unionism" to conditions of the "new economy". First, we might ask: can labor unions use IT to better

99. Castells, Rise of the Information Society.

ı००. Peter Whalley and Stephen R. Barley, "Technical Work in the Division of Labor: Stalking the Wily Anomaly", in Stephen R. Barley and Julian E. Orr (eds), Between Craft and Science: Technical Work in US Settings (Ithaca, NY, 1997), pp. 23-52.

IоI. Anthony M. Townsend, Samuel M. Demarie, and Anthony R. Hendrickson, "Information Technology, Unions, and the New Organization: Challenges and Opportunities for Union Survival”, Journal of Labor Research, 22 (2001), pp. 275-287. 
motivate nonunion workers to organize? Alistair Mutch has recently suggested that historically information access has been crucial to tradeunion effectiveness, especially in times of technological change. ${ }^{102}$ Yet Gary Chaison recently feared that in the present information environment,

As unions deepen their Internet presence to compete against employercontrolled intranets, they can begin to do through their web pages what they would otherwise do through personal contact with members. Union resources and effort can be shifted away from activities requiring personal contact such as meetings, rallies, and social activities and toward the faster and less expensive promotion of an Internet presence. The union web page can become the primary means to communicate with members. Organizing can simply mean developing a website to attract potential members, connect them with online organizers, and collect digital signatures on union authorization cards. ${ }^{103}$

Thus the active union member might be reconstructed along neoliberal lines as simply a consumer of value-added services.

Secondly, we might ask: can IT workers in particular be motivated to organize at all? In one recent exploratory study of the attitudes of programmers, systems engineers, and software engineers toward labor unions, the researcher found that

When asked about whether they had ever thought of joining a union, every hightech worker interviewed responded with silence, and in several instances with prolonged silence. To a person, they said that they had never thought, even once, of ever joining a union or engaging in collective action to improve their working conditions. ${ }^{104}$

This study only dealt with a handful of respondents, but it reflects the general tone of the technical and business literature in suggesting that IT workers are an unnatural fit for traditional labor organizations. Yet if we expand our definition of "information workers" along the lines above involving workers from the communications, media, education, and office administration fields - suddenly unions are everywhere. Information workers in the "physical internetwork" of information communication (UPS, FedEx, and the Post Office in the US) have been involved in organizing efforts throughout the I990s, culminating in a UPS strike which shocked the nascent world of e-commerce with demands to end part-time labor, reduce overtime, and extend health benefits to all. ${ }^{\text {Ios }}$

102. Alistair Mutch, "Unions and Information, Britain 1900-1960: An Essay in the History of Information", International Review of Social History, 44 (1999), pp. 395-4I7.

103. Gary Chaison, "Information Technology: The Threat to Unions", Journal of Labor Research, 23 (2002), pp. 249-259.

104. Laurie P. Milton, "An Identity Perspective on the Propensity of High-Tech Talent to Unionize", Journal of Labor Research, 24 (2003), pp. 3 I-53.

I05. Richard Rothstein, "Union Strength in the United States: Lessons from the UPS Strike", International Labour Review, I36 (1997), pp. 469-492. 
Finally, we might ask: how have labor unions themselves changed with the introduction of IT? A senior research analyst with the International Brotherhood of Teamsters recently pointed out that his organization uses "a database of contract information for over 200,000 Teamster collective bargaining agreements (both expired and current)" through which they track "nearly 40,000 separate employer-union relationships". ${ }^{106}$ In the US, even under the return of a labor-hostile conservative administration in 2000, such efforts have generated great enthusiasm for an IT-driven New Labor movement, with some longtime activists hoping that "Ongoing efforts by the AFL-CIO and its 66 affiliates to maximize their creative use of computer power may help slow, stem, and finally reverse Labor's decline in union density." I07 But it may be in reaching out beyond union members themselves that labor organizations use IT most effectively. Consider again the case of global retailing leader Wal-Mart Stores, Inc. - a firm so effectively enmeshed in the space of flows of consumer commodities that it did \$2I8 billion in sales in 2002 among its 4,300 outlets worldwide. Potential Wal-Mart workers, consumers, or even hosting communities concerned about the health care benefits offered to the firm's I.3 million employees don't have to simply rely on the claims on the company's website that "[t]he company contributes to the cost of health benefits" such that " 60 per cent of our Associates tell us they joined Wal-Mart because of our benefits". ${ }^{108}$ They can also explore the website, Wal-Mart Watch, maintained by the United Food and Commercial Workers Union (UFCW), to discover that "[s]trict eligibility requirements, huge employee co-pays, and big deductibles keep participation in Wal-Mart's health plan to 38 per cent of employees", leaving " 425,000 employees - most of them women workers - who don't get health coverage from Wal-Mart". ${ }^{109}$ Each site makes Wal-Mart labor visible in a different way. Web-surfers with access to both sites - theoretically from anywhere around the globe - can thus make their own decisions about the accuracy and import of these contested claims.

\section{MAKING INFORMATION LABOR VISIBLE IN THE HISTORICAL RECORD}

In a similar way, this supplement has been an attempt to correct the historical narrative in which information labor is left invisible - assumed to be technologically determined, deemed unimportant to historical

I06. Robert E. Lucore, "Challenges and Opportunities: Unions Confront the New Information Technologies", Journal of Labor Research, 23 (2002), pp. 201-21 $5,208$.

107. Arthur B. Shostak, “Today’s Unions as Tomorrow's Cyberunions: Labor's Newest Hope”, Journal of Labor Research, 23 (2002), pp. 237-249, 237.

I08. Wal-Mart Stores website, http://www.walmartstores.com; last accessed Io June 2003.

I09. Wal-Mart Watch website, http://www.walmartwatch.com; last accessed I० June 2003. 
explanation, or somehow not cast as "labor" at all. We were surprised and delighted with the broad range of methodological approaches our authors took in challenging this narrative, including the exploration of diverse historical contexts, the use of ethnographic methods, and the engagement with important geographic concepts of space and time.

In the sense of context, the sites of IT labor discussed in this supplement range from eighteenth-century Germany, and nineteenth-century India, to twentieth-century South Africa and twenty-first-century Silicon Valley, pointing out the diverse ways in which IT revolutions are enacted, experienced, and contested on the ground in different times and places. In identifying just what kind of IT-related work was being performed in those contexts, our authors illustrate a consensus out of this diversity: the proper definition of information labor is not simply "knowledge work", but also the labor involved in producing and reproducing information infrastructures themselves, as well as more traditional production and service work under any new regime of informatization. For example, Eve Rosenhaft's "Hands and Minds" piece, in describing the eighteenthcentury German survivor's pension funds, shows how pension clerks were implicated in two important new informational processes: the application of state-gathered mathematical statistics to profit-making business, and the advertising of investment opportunities to a population through the mass media. ${ }^{110}$ Bernard Dubbeld, in his article on "Breaking the Buffalo", considers the containerized commodity-shipping network and its manifestation in Durban, South Africa. His narrative describes a key turning point in both a nation and an industry, on one hand representative of a shift to a global, real-time, networked information economy, but on the other hand quite historically, geographically and culturally contingent on a cultural legacy of apartheid and a local history of stevedoring. ${ }^{\text {II }}$ And in their article "Compressing Time and Constraining Space", Helen Sampson and Bin Wu offer another lens on the story told by Dubbeld, using a focused study of the port of Rotterdam to explore the shifts in the spatial/ temporal division of labor in the global shipping industry due to both onboard information/communication technology and in-port container/ transport technology. Their history and interviews reveal how IT has transformed the physical calculating and monitoring of hull stresses and loads, both in terms of who does the work (officer or engineer) and where it is done (ship or shore). ${ }^{112}$

In the case of sources, too, our authors prove innovative. Though all the

I Iо. Eve Rosenhaft, "Hands and Minds: Clerical Work in the First 'Information Society”, pp. I3 -43 .

I I I. B. Dubbeld, "Breaking the Buffalo: The Transformation of Stevedoring Work in Durban between 1970 and 1990", pp. 97-I22.

I r. Helen Sampson and Bin Wu, "Compressing Time and Constraining Space: The Contradictory Effects of ICT and Containerization on International Shipping Labour”, pp. I23-i 52. 
articles in this volume rely on traditional historical methods of archival research and subject interview to one degree or another, many employ ethnographic interview, observation, and participation methods as well. The opportunity to employ such first-hand techniques is rare in historical research, but when dealing with a contemporary subject like the IT revolution, in which social and spatial conditions are changing so rapidly, attention to recent history is a must. After all, one of the goals of history is to provide a sort of cultural anthropology of the past. ${ }^{\text {II } 3}$ For example, in studying the recent changes in global shipping labor, Sampson and Wu talked to laborers of varying status, both on the shore and on the ship, and in the process were able to analyze how those very spatial categories of "ship" and "shore" were themselves in flux due to the way IT was put to use. Similarly, Chris Benner's essay on "Computers in the Wild” follows, first hand, the changing nature of labor "guilds" in Silicon Valley, through tumultuous years of $\mathrm{Y}_{2} \mathrm{~K}$ fear and fervor, dot-com boom and bust. His study reveals not just the historical views of his actors in a specific time and place, but the changing geographical sense of what that place itself means, as both a labor market and a home. "Information" in Benner's view is not simply a commodity produced and consumed in the for-profit "content industry". Rather, information of another sort - tacit knowledge of the way complex technologies perform on the job "in the wild" - is also traded throughout a diffuse but active labor market. ${ }^{\text {II }}$

Finally, in applying historical and ethnographic methods to these contexts, many of our authors have also developed a keen sense of geographic awareness, which is often missing from work in the humanities and social sciences. In an obvious sense, these articles range over many different spatial locations of information labor - not just laboratories of IT innovation and offices of IT application, but places like those "electronic cottages" where individuals blur the lines between home and factory, and the docks and ships where the infrastructures of immaterial and material commodities merge to enable our current wave of globalization. But in a more subtle sense, our authors have taken the notion of space/time transformation as a key principle of IT labor itself. Deepak Choudhury in particular uses spatial analysis to understand the labor actions of telegraph workers under a regime of global empire in his story of the turn-of-thecentury multi-stage telegraph strike in colonial British India and Burma. ${ }^{\text {II }}$ Choudhury illustrates how a "virtual community" of labor, separated over regional distance but connected by electromechanical communication,

I 13. Anthony F.C. Wallace, Rockdale: The Growth of an American Village in the Early Industrial Revolution (New York, 1972).

I I4. Chris Benner, "Computers in the Wild': Guilds and Next-Generation Unionism in the Information Revolution”, pp. i 81-204.

I I 5. D. Choudhury, "India's First Virtual Community and the Telegraph General Strike of I908”, pp. 45-7I. 
could mobilize to act. Further, he argues that membership in that virtual community overcame (if only momentarily) persistent boundaries of race, class, and ethnicity - divisions which have historically been mobilized quite effectively by capital to reinforce less costly and more docile divisions of labor. The fact that Choudhury's tale took place nearly a century ago both contradicts and gives hope to the views of present-day Internet advocates such as Mark Poster, who recently claimed "the only way a movement can be constructed of workers on a global scale is through the Internet". ${ }^{116}$ Still, we must remember that however virtual it may have seemed, the strike was important precisely because it was grounded in particular physical places - places of strategic and economic importance to the wider British Empire.

Given the varied historical, ethnographic, and geographic perspectives of the pieces in this volume, then, I would like to point to four general and dialectical themes which emerge from these articles as working hypotheses about information labor:

\section{It takes technological labor to build and sustain new labor-saving technological infrastructures}

In theorizing the production and reproduction of the urban built environment under capitalism, David Harvey has argued that "Under capitalism there is [...] a perpetual struggle in which capital builds a physical landscape appropriate to its own condition at a particular moment in time, only to have to destroy it, usually in the course of a crisis, at a subsequent point in time." To Harvey, this process represents a dialectic, a contradiction which capitalism as a whole needs to resolve continually, time and again, in order to continue to be profitable and productive:

In order to overcome spatial barriers and to annihilate space with time, spatial structures are created that themselves act as barriers to further accumulation. These spatial structures are expressed in the form of immobile transport facilities and ancillary facilities implanted in the landscape. We can in fact extend this conception to encompass the formation of the built environment as a whole. ${ }^{117}$

Something similar happens in the application of technology to production, especially information technology. In order to innovate a new technological environment for the purposes of making labor more efficient, more productive, more easily managed, more flexible, or even less necessary, capital must invest labor in the production of new standards, new infrastructure, and new skills. But these technological innovations are rapidly taken on by all competitors and then become a

I 17. David Harvey, The Urban Experience (Baltimore, MD, 1989). 
barrier to further innovation - until, that is, additional labor is mobilized to modify or replace those barriers once again.

Aristotle Tympas's insight into "Computing Electric Power Transmission Before the Electronic Computer" illustrates this dialectic by describing how complex, networked infrastructure systems of all sorts are necessarily underpinned by similarly complex information systems, both during their design and in the course of their functioning. ${ }^{118}$ The human "computors" that Tympas discusses have been absent from recent information history, but are much on the minds of contemporary writers. In bringing them to our attention, Tympas effectively weaves the stories of three kinds of technologies: the electrical infrastructures normally conceptualized as solely the work of "system builders"; the ad-hoc electromechanical tools such as "network analyzers" which were built explicitly to solve mathematical and physical problems of infrastructure construction and operation; and the individual laboring "computors" embedded in both of these technological webs, whose expertise in operating the analysis tools was both necessary and undervalued.

The article by Nathan Ensmenger on "Letting the 'Computer Boys' Take Over" considers the next chapter of this innovation saga: the birth of the new-job category of "computer programming" within the for-profit firm, where programmers mediated between the new technology of electronic computers and the existing corporate social environment. ${ }^{119}$ According to Ensmenger, programmers were caught in a bind: while they acted as enablers of a new, highly-valued corporate practice - electronic data processing - they also served as a lightning rod for criticism of the feared consequences of that same practice - organizational restructuring. This very tension in the new programming occupation helps to explain the historical origin and subsequent reproduction of the idea of a "software crisis" - both a recurring justification for rationalizing the labor of programmers under management control, and a constant lure for attracting more job-seekers to the field of computer programming itself.

\section{Any changing technological division of labor is involved in a changing social division of labor as well}

This idea is not meant to invoke technological determinism (as discussed above), but is meant instead to suggest the complex relation between technology and culture. For example, Ensmenger hits on just such a relationship when he observes that computer programming, the act of

I 8. Aristotle Tympas, "Perpetually Laborious: Computing Electric Power Transmission Before the Electronic Computer", pp. 73-95.

I I9. Nathan L. Ensmenger, "Letting the 'Computer Boys' Take Over: Technology and the Politics of Organizational Transformation”, pp. I53-I80. 
instructing machines to act in deterministic ways in order to rationalize human business processes, was itself as a "craft" skill which apparently demanded a new "science" of the management of computer programming. This contradiction structured the different ways that managers attempted to exert control over their new and necessary computer-programmer labor force - from screening out all but the (supposed) best programmers, and paying higher salaries for only the most innately talented designers, to purchasing programming language packages which would allow the most unskilled programmer to produce adequate code, and learning a new systems-oriented management style themselves.

Similarly, Dubbeld describes how the Durban stevedores moved from "permanently casual" workers (in that they forged an intermittent work life in a single city) to "permanent apartheid" workers (their labor administered centrally and controlled by the state), to unionized workers (under conditions of increasing containerization), and finally back to "casual and flexible" workers (especially under new IT-enabled labor management systems). In the end, unions failed to protect these workers' interests: space was rationalized, time compressed, ownership consolidated, industrial links (between shipping, rail and road companies) tightened, and work-gangs (with their level of control over the labor process) first reduced in size, then subject to "multiskilling", and finally abandoned. This story reminds us that large-scale economic restructurings of international telecommunications, shipping, road, and rail infrastructures are global but not homogenous; when combined with the legacy of apartheid, the outcome was necessarily contingent. In the case of the US, for example, Ann Schwarz-Miller and Wayne K. Talley recently argued that the combination of transport technology, information technology, and neoliberal de- and reregulation have cut the number of railroad industry employees by half, vastly weakening their bargaining power, but have had "a positive effect on the demand for dockworkers", rather improving their bargaining position. ${ }^{\mathrm{I}}{ }^{20}$ (Though this strong position was not enough to avoid a major West-Coast longshoreman lockout in Autumn 2002 - just before the e-commerce holiday rush.) $)^{\text {I2I }}$

\section{Any changing technological and social division of labor is involved in a changing spatial and temporal division of labor as well}

Even in industries which don't produce informational products or services, the application of information technologies almost always creates

I 20. Ann Schwarz-Miller and Wayne K. Talley, "Technology and Labor Relations: Railroads and Ports", Journal of Labor Research, 23 (2002), pp. 513-534.

I 2 I. Steven Greenhouse, "Labor Lockout at West's Ports Roils Business", New York Times [online] (I October 2002). 
new time-space conditions (just as the application of mechanized technologies created new time-space conditions in the Fordist factory). Commenting on the recent history of the trucking industry in the US, Michael Belzer has argued that under government deregulation (and driver/union reregulation), "advances in information technology have been adopted throughout the trucking industry to enhance carriers' competitiveness and meet customers' demands. This new technology increased the performance pressure on drivers and dockworkers who must meet more stringent time schedules under adverse conditions." Such technology is now so sophisticated that it "can be used to track driver activities as well, changing a formerly unmonitored job (suited to piece work and efficiency wages) into a monitored one. Carriers now know the location of their truck to within a few hundred feet". ${ }^{\mathrm{I} 2}$

On the surface, the technological changes at work between ship and shore labor in Sampson and Wu's account of Rotterdam might seem to fit unproblematically with the historical narrative of "automation" described above: cranes, containers, and computer-mediated communications all help to decrease turnover time and decrease labor requirements, resulting in the capitalist's increase in both productivity and profit. Yet Sampson and Wu point out that not only are shore-based workers still required, but their spatial/temporal relationship to the ship-based staff has changed dramatically, with contact between the two groups now kept to a bare minimum. Aboard ship, the duties of various grades of officers have been redefined to incorporate new kinds of information management required by the shore office. But this routinized communication of data helps keep the ship-based staff out of casual communication with the dock staff. With new time and information requirements linked to computerization and containerization, and with the most modern ports (like Rotterdam) located far away from old city centers, the laborers themselves experience space/ time horizons which are perhaps more constrained than ever before, even as the commodities they carry and the capital they generate both move more freely.

\section{Information laborers from diverse social categories find their positionalities become bound up in the cultural understanding of the information technology itself}

This final point considers how the qualities of laborers become attached over time to the qualities of a certain kind of labor - and vice versa. Tympas describes a dialectic between the roles of "analyst" (often male)

I22. Michael H. Belzer, "Technological Innovation and the Trucking Industry: Information Revolution and the Effect on the Work Process", Journal of Labor Research, 23 (2002), pp. 375 $396,376,390$. 
and "computor" (often female), arguing that with each advance in electromechanical calculating technology, the two labor categories were continually redefined to valorize the one and deemphasize the other. Not only was there a gendered division of labor in network analyzer work; but conceptions of analog devices and manual labors were devalued hand-inhand with the feminization of those tools - arguably a fundamental step in the development of today's assumption that digital technology is (by definition) naturally superior to analog. Rosenhaft, in the most biographical of our articles, puts particular focus on key career moments of three "minor functionaries" of her information economy - male workers with foothold in the "middle class", relying not only on important numeracy and literacy skills, but on a tenuous web of social obligations. Rosenhaft illustrates that the importance of the rapid and accurate processing of information (not to mention the advertising of that informational power) was not only recognized by the eighteenth-century actors themselves, but was wrapped up in negotiations over personal reputation, the definition of a just living wage, the demands of absolute secrecy, and the fears of clerks using their informational capital to set up shop themselves.

What these examples share is a notion that "class" is a relation, a process, a positionality with respect to capital; not a thing. ${ }^{123}$ Certainly class involves abstract Marxian social relations between the purchaser of labor power and the seller of labor power. But it also involves abstract cultural categories like "middle-class", "urban", and "professional" - all historically-specific social constructions of who is "valued", who is "educated", who is "high-tech" in any given economy and society. Thus, technologies become naturalized in difference-specific ways - for example, the masculinization of computer programming and the feminization of content production which I witnessed in my own career.

Hector Postigo's article describing "The Case of America Online Volunteers" addresses this question of positionality by exploring the creation of a labor identity in the case of the "volunteers", who both consumed and produced content in the nascent for-profit online service AOL. ${ }^{24}$ Instead of considering the programmers of Ensmenger's study or the content designers of Benner's study, Postigo looks at a hybrid category of content producers - they neither programmed the infrastructure that made AOL work, nor designed the elements of AOL's “look and feel”, but they did take on responsibility for the content which populated this infrastructure, and for the crucial ad-hoc communication with new subscribers (not just subscribers new to AOL, but subscribers new to

I 23. David Harvey, Justice, Nature, and the Geography of Difference (Cambridge, MA, I996), p. 359 .

I 24. Hector Postigo, "Emerging Sources of Labor on the Internet: The Case of America Online Volunteers", pp. 205-223. 
the entire idea of computer-mediated communication). The historical changes that these AOL volunteers experienced illustrate the thorny social relations at work: there was a consumption aspect, where AOL volunteers received reduced subscription prices or "free hours" to spend at their leisure; there was a training aspect, where volunteers hoped to learn marketable skills and advertise their experience with AOL on a résumé to other firms; and there was a labor aspect, since AOL volunteers worked long hours and demanded at least recognition and respect if not remuneration. Postigo's story shows how these intertwined social relations of training, production, and consumption worked to build another social relation: virtual solidarity of a sort between members of the volunteer community itself. But this community was distinct from other organizations of laborers because of its invisible nature: it was unclear how many members there were; an alternate site, outside of AOL itself, was required to access the community; and only certain computer-mediated actions could easily occur there. Now that it has been made visible, we can ask whether this community gained its identity from AOL or in opposition to AOL.

\section{NOT A CONCLUSION, BUT A BEGINNING}

The articles in this volume illustrate that tracing the history of complex, parallel, and intertwined changes among technologies, spatiotemporalities, and human labors is no easy task - and trying to do so in real time is even harder. Information labor often doesn't map easily on to any single category of "class", and information technology itself is often dialectically involved in redefining social norms not only of class membership but of other social categories as well. I would argue that academics (and activists) need all the tools they can get to meet this challenge of interpretation and understanding. Historical contextualization, ethnographic interpretation, and geographical awareness are three sets of tools which I try to use in my own work, and which, I am pleased to see, have been put to good use in the articles of this volume.

But where do such snapshots of the "IT revolution" leave us? Some find it tempting to predict a new social revolution arising from this technology and labor revolution:

Marx and many other writers have pointed out that social relations eventually must correspond to the level of productive forces. We now live in a time when productive forces have raced far ahead of social relations. The knowledgeintensive productive forces are straining against the chains of private property relations. The qualities of knowledge, to be fully maximized, require a system based on cooperation and sharing, because cooperation and sharing generates more information and social wealth. Such a system would emphasize education, because education builds the infrastructure for expanding social wealth. Such a 
system would require the distribution of goods on the basis of need, because the [low] cost of production eliminates scarcity and wages. This, of course, is a radically different system. ${ }^{\mathrm{I} 25}$

Yet others have argued against such naturalized change, fearing "the 'new knowledge/service economy' produces its own proletariat - in call centers, on assembly lines for producing high-tech products, and to service the continuing need for cleaners, security guards, waitresses and waiters". ${ }^{26}$ As this volume illustrates, such debates are not new. But can we as historians offer any kind of new response?

I hope we can. Today's digital-divide discussions - whether focused on inequalities between households, schools, regions, or nations - inevitably encompass normative claims (overt or hidden) about the state of labor in the current and future information age. Our historical narratives can help reveal some of the contradictions found between the public investment in the development of information infrastructures (from semiconductors and programming languages to satellite communications and the Internet) versus the private monopoly on profit from the services and commodities that are subsequently developed using these infrastructures. Thus might we both write a labor history - with laborers themselves as units of analysis - and use that labor history as a lever for wider societal changes.

I 25. James Davis and Michael Stack, "Knowledge in Production", Race E Class, 34:3 (1993), pp. I-I 4; repr. in Philip E. Agre and Douglas Schuler (eds), Reinventing Technology, Rediscovering Community: Critical Explorations of Computing as a Social Practice (Greenwich, CT, I997), pp. $56-7$ I.

I26. Amin, Massey, and Thrift, Cities for the Many, p. 22. 